\title{
Pluractional Verbs: An Overview
}

\begin{abstract}
Almost three decades ago, I proposed the term PLURACTIONAL to describe verb forms whose function was to indicate plurality of action or event (Newman 1980). In the intervening years, there has been increased interest in the phenomenon by scholars working in many areas of linguistics from phonology to morphology to semantics. There has also been widespread adoption of the term, to the point where it was deemed familiar enough to warrant a head entry in the Elsevier Encyclopedia of Linguistics (Newman 2006) and in the Dictionnaire de Sémantique (Laca 2006). This paper is organized into four parts. Part I consists of an overview of the pluractional concept. In Part 2, I describe the introduction and adoption of the term. In Part 3, I discuss generalizations about pluractionals that one can draw from the range of studies now at our disposal. In Part 4, I present what I consider to be unanswered questions about pluractionals that deserve increased attention by descriptivists, theoreticians, and typologists.
\end{abstract}

\section{The pluractional concept}

\subsection{Overview}

Many of the world's languages have a "pluractional" verb form that specifies that "the verbal action is characterized by one or another kind of multiplicity: it can happen habitually; it can be executed by a certain number of subjects; it can be applied to a certain number of objects; it can continue over a longer period of time; or it can be performed at different places" (Gerhardt 1984: 12). In Hausa, pluractionals have been described as involving "one actor, or a number of actors doing the same thing to a number of objects, either simultaneously or in succession; or a number of actors doing the same thing to the same object severally and/or in succession; or else one actor doing the same thing to the same object several times over.... With intransitive verbs it adds a notion of multitude and/or succession ... or sometimes of distribution in space" (Parsons 1981: 206). The semantic characterizations of pluractionals provided independently by other scholars are similar: "The reduplicated [i.e., pluractional] verb stems [in Margi] usually indicate iterative, intensive, or extensive action. They may also point to the plurality of the subject (if intransitive verbs) or of the object (if transitive verbs)" (Hoffmann 1963: 160). "The 
plural [i.e., pluractional verb] [in Kisi] can signify that the action was repeated many times, either at one instant or over a period of time. It can mean that there was more than one agent, more than one patient, or even that there is more than one beneficiary, depending on the semantics of the verb (and its other extensions)" (Childs 1995: 194). "What is plurality in the verbal domain? In many languages pluractional markers attach to the verb to indicate a multiplicity of actions, whether involving multiple participants, times or locations... [W] e seem to have an analog in the domain of events to the more familiar phenomenon of plurality in the domain of individuals..." (van Geenhoven 2004: 153). "The term plural verbs (or pluractional verbs) ... refers to any or all of the following senses: the action is performed several times (iterative), or at several places (distributive), or the action affects or involves several participants" (Veselinova 2008).

\subsection{Development of the concept}

The existence of plural verbs and related categories such as iterative, repetitive, and distributive has been documented in scattered publications over a long period going back to the early 20th century and covering languages and language families as diverse as Dravidian (Winfield 1928), Coptic (Vycichl 1970), Sumerian (Steinkeller 1979), Semitic (Greenberg 1991), and, in the case of Native American languages, representing the insights of leading figures such as Boas (1947) and Sapir (1917) (see also Sapir \& Swadesh 1946). The classic volume that delves into the subject of verbal plurality is Dressler (1968). The modern linguistic appreciation of the significance of these earlier works and the recognition of verbal plurality as a rich and complex area of study can be said to have begun in the early to mid 1980s with the appearance of an oft-cited Ph.D. dissertation (Cusic 1981) and the publication of a series of influential papers by Bybee (1984, 1985), Frajzyngier (1985), Durie (1986), and Mithun (1988), in all of which disparate examples of verbal plurality were regarded as manifestations of a common phenomenon. More recently, pluractionality has been treated in depth in a still unpublished, firstrate Ph.D. dissertation (Wood 2007). ${ }^{1}$

What emerged from these studies is an understanding that the phenomenon that increasingly came to be known as pluractionality involved (a) plurality in the verb per se, (b) derivation rather than inflectional agreement, (c) ergativetype relations with other arguments in the sentence, (d) reduplication as a common means of formation, and (e) the common appearance of suppletive forms. 


\section{The term "pluractional"}

\subsection{Introduction of the term}

In discussing Afroasiatic verb stems formed with internal consonant gemination I wrote, 'In my opinion these verb forms represent, not 'Present' stems, but rather iterative, habitual, intensive, or, what I prefer to call, 'pluractional' stems" (Newman 1980: 13n). This statement represents the first use in print of the term pluractional, a coinage based on the phrase "plurality of action". I again used pluractional in a paper that appeared the following year: "Instead of the misleading term 'intensive', which is normally used in the Hausa linguistic literature, the first author [Newman] has proposed the neologism 'pluractional' verbs" (Newman \& Salim 1981: 110n). That same year the term was employed in a phonetic study of Hausa by R. M. Newman \& van Heuven (1981). A few years later, the new term graduated from casual mention to front stage by being used in the title of a paper describing the diachronic development of pluractional formation in Hausa (Newman 1989). The following year saw the publication of a book length study of plurality, verbal as well as nominal, consisting of a comparison of related formations in languages throughout the Chadic family (Newman 1990). By the time my Hausa reference grammar appeared (Newman 2000), the term was well enough established and the phenomenon well-enough known - at least by Chadicists and Hausaists - that it seemed natural to include a separate unit (chapter 55) on "Pluractional Verbs".

\subsection{Motivation for the term}

As far as Hausa is concerned, the initial impetus was the need for a more appropriate label to replace the prevailing term "intensive", whose semantic inaccuracy had been commented on directly by Gouffé (1975: 306): "Les thèmes dits 'intensifs' expriment en réalité la pluralité du procès." However, it seemed clear from the outset that the neologism was needed for general linguistic purposes that went far beyond the specific needs of Hausa.

First, "pluractional" served to distinguish verbs indicating plurality of action or event from so-called plural verbs reflecting subject-verb agreement, a distinction whose existence had already been noted: "The category of number in verbs is found in two different ways. Verbs may agree with their subject in number or more frequently in number and person. There are also languages in which the verb itself has singular and plural (sometimes also dual) stems which indicate singularity or plurality of action. In such cases plurality in-

\footnotetext{
1 Unfortunately I was unaware Wood's thesis at the time that I prepared this paper.
} 
cludes plural subject and/or plural object or frequentative action" (Greenberg 1966: 79). The problem, as I pointed out, was that linguists lacked a terminological distinction corresponding to the structural/ functional distinction: "The term 'plural' when applied to verbs tends to be used indiscriminately for two distinct grammatical categories, namely, inflected plural verb forms required by a conjugational concord system ... and derived plural verb stems denoting semantic plurality... It seems to me that the use of the term 'plural verb' to refer to both types of verbal plurality has impeded our understanding of the non-concordial forms. Therefore ... I coined the term 'pluractional' in order to set apart the semantically endowed verbal plurals from the inflectional agreement stems" (Newman 1990: 53).

Second, "pluractional" provided a cover term to bring together the morphologically similar forms in the languages of the world that had previously been described as intensive, iterative, habitual, durative, frequentative, distributive, and plural action, not to mention plural verb. A common term was needed so as to allow cross-language comparison, whether for theoretical, typological, or phylogenetic purposes. For example, "pluractional" had the advantage of relating the Hausa forms more clearly to similar verb forms in other Chadic and Afroasiatic languages and helped us recognize the existence of similar linguistic phenomena in languages of Africa, Asia, and the New World.

\subsection{Acceptance and adoption of the term}

\subsubsection{Sub-Saharan Africa}

a. Chadic/Afroasiatic. Although "pluractional" was a useful and convenient term, as has been shown by its subsequent widespread adoption, it took time to catch on. At first, the only people who knew of it were colleagues and students with whom I personally worked. With the publication of my Chadic plurality book (Newman 1990), the term "pluractional" became increasingly familiar to Hausaists and Chadicists and was adopted by leading scholars in the Chadic field such as Russell Schuh at UCLA and Philip Jaggar at SOAS. At first scholars made casual reference or passing use of the term, but before long it began to be employed seriously in descriptions not only of Hausa but of other Chadic languages. Over the past dozen years, the term has increasingly begun to appear in the titles of articles, e.g., "Pluractionals in Bole" (Gimba 1995), "Avoidance of the marked in Miya pluractional allomorphy" (Bissell 2002), "The locus of pluractional reduplication in West Chadic" (Schuh 2002), and "Intensive plurality: Hausa pluractional verbs and degree semantics” (Soucková \& Buba 2008). 
Given that the term was first used in Chadic, which is a constituent member of the Afroasiatic phylum, and the fact that the existence of reduplicated verbs connoting iteration, repetition, durativity, and plural action have long been documented in other branches of Afroasiatic, see, for example, Fassi Fehri (2003) and el Zarka (2005) for Arabic, Frajzyngier (1979) for wider Semitic, and Vycichl (1970) for Coptic, it is not surprising that once Afroasiaticists were introduced to the term, they found it to be apt and useful. We thus find "pluractional" having been adopted by scholars working in all branches of Afroasiatic, e.g., Ancient Egyptian (Bendjaballah \& Reintges 2009); Semitic [Arabic] (Zaborski 2006) and [Modern Hebrew] (Y. Greenberg 2010); Cushitic [Somali] (Lecarme 2004) and [Konso] (Mous n.d.); and Berber [Tuareg] (Kossmann 2004, Dingemanse 2008).

b. Other African Languages. The key publication that brought the term to the attention of general Africanist scholars was "Pluractional verbs in African languages" (Brooks 1991), a paper written by a then undergraduate student of mine. In the years that followed, the term underwent adoption at an increasing pace. Scanning the scholarly literature of the past decade, one comes across examples of "pluractional" being employed in descriptions of African languages spoken across the continent and belonging to all of the major African phyla. For example, in Niger-Congo, "pluractional" is found in studies of Jukun and Izere [Nigeria] (Blench 2005, n.d.), Benue-Congo languages of the Jos Plateau [Nigeria] (Gerhardt 2002), Gurene and Dangme [Ghana] (Kropp Dakubu 2003), Mundang [Adamawa-Ubangi] (Elders 2001), the Atlantic language group (Becher 2002), East African Bantu (Nurse \& Philippson 2003), Ngomba [Grassfields Bantu] (Satre 1999), and, most prominently, in the analysis of Leggbo [Nigeria] by Hyman (2009). Within Nilo-Saharan, the term is employed in describing Datooga [Nilotic] (Kießling 1998) and Ngiti [Nilo-Saharan:Sudanic:Ngiti] (Dimmendaal 2003). In Khoisan (and suspected Khoisan) languages, the term is used in analyses of $=$ Hoan (Collins 2001) and Sandawe (Kießling 2002, Creissels et al. 2008).

What has helped spread familiarity with the term has been its use in recent years in major African linguistics works by leading practitioners in the field. For example, the term is employed by other authors and myself in Heine \& Nurse (2000), a successful introduction to African linguistics, which since 2004 has also been available in a French translation. When we get to the latest general work by Heine \& Nurse (2008), the term is used throughout as a normal, fully accepted part of linguistic terminology (see especially Kießling, Mous, \& Nurse 2008). Similarly, in the broad presentation by Hyman (2007), one of the world's most prominent Africanist linguists, his analysis draws readily on the pluractional concept and the related term. 


\subsubsection{Non-African}

In his excellent study of number published barely a decade ago Corbett (2000: 243n) wrote: "Newman (1980) suggested the term 'pluractional', but use of this term is largely limited to Africanists." Although this may have been true at one time, it is no longer the case. As with the term ideophone, which started out as an Africanist term, but which has now become commonplace in general linguistics, so we find that pluractional has broken out of its Africanist origins.

a. Americas. Since much of our understanding of intrinsic verbal plurality came from the perceptive descriptions and analyses of Native American languages, it was only a matter of time before the term would become part of the vocabulary of scholars working on these languages. In North America, "pluractional" has been used in publications on Yurok (Garrett 2001, Wood \& Garrett 2001), Salish (Shaw 2005), Paiute (Houser, Kataoka, \& Toosarvandani 2006), Squamish (Bar-El 2008), Washo (Yu in press), and comparative Siouan (Souag 2008), not to overlook West Greenlandic (van Geenhoven 2004), a language closely related to Eskimo/Aleut. In Meso- and South America, "pluractional" has been used in describing Guarijio [Mexico] (Caballero 2006), Cusco Quechua [Peru] (Faller 2007), Itonama [lowland Bolivia] (E. I. Crevels 2006, M. Crevels n.d.), and Karitiana [Amazonia, Brazil] (Müller \& Sanchez-Mendes 2007).

b. Elsewhere. In Asia, Australia, and the Pacific, we find "pluractional" being employed in describing Korean (Kwak 1996 [following Lasersohn (1995), see below]), Jingpo [Tibeto-Burman] and Malay (Gu, Liu, \& Yap 2007), Tagalog (Zuraw 2002), Bardi [Australia] (Bowern 2004), Kuot [Papuan] (Lindström 2002), Trukese (Yu 2007), and Niuean [Polynesian] (Haji-Abdolhosseini, Massam, \& Oda 2002). In the Caucasus, the term has been incorporated in excellent descriptions of Chechen (Yu 2003, Wood 2007) and the related Ingush (Bruhn 2007).

\subsubsection{General linguistics (morpho-phonology and semantics)}

Over the past decade, research in a number of areas has stimulated interest in pluractional verbs as a general linguistic phenomenon and has helped spread familiarity with the term. One can particularly point to current work in phonology and semantics.

a. Phonology. Recent years have seen an ever-growing attention to reduplication as a phonological/morpho-phonological phenomenon. Studies of import- 
ance include the book by Inkelas \& Zoll (2005) and the collected volume by Hurch (2005), see also Kouwenberg (2003). Treatment of reduplication from a historical perspective is found in my monograph on Klingenheben's Law in Hausa (Newman 2004). This focus has naturally resulted in attention to pluractionals, where reduplication is an extremely common formation.

b. Semantics. An essentially independent interest in pluractionals has been shown by people working in the field of semantics, some of whom are scholars whose work fits into a traditional linguistic framework while others are theoretical linguists and philosophers dealing with questions of formal semantics. The starting point here is undoubtedly Peter Lasersohn's influential book Plurality, Conjunction, and Events (1995), which includes a full chapter on pluractionals. His approach is reflected in and continued by such scholars as Zimmermann (2003), Matthewson (2004), and van Geenhoven (2004, 2005). The impact of the pluractional concept on semantics is shown by the many works with the term "pluractional" in the title that have appeared over the past decade. Examples include: "On distributivity and pluractionality" (Matthewson 2000), "Pluractional quantifiers: The occasional-construction in English and German" (Zimmermann 2000), "Progressives, pluractionals, and the domains of aspect" (Laca 2004), "Pluractional adverbials" (Beck \& Stechow 2007), "The semantic typology of pluractionality" (Wood 2007), "Pluractionality in Romanian event nominalizations" (Iordachioaia \& Soare 2007), and "Event internal pluractional verbs in some Romance languages" (Tovena \& Kihm 2008). A consequence of treating pluractional as a semantic concept is that one now finds the term being used to describe such languages as English, German, French, Italian, Romanian, Slavic, Hindi, Turkish, and Finnish, which do not have morphological pluractionals as traditionally conceived, but which do manifest pluractionality in a broader sense.

\section{Substantive generalizations regarding pluractionals}

\subsection{Widespread}

Pluractionals are widely found as a morphologically marked verbal category in the world's languages. They are not limited to specific areas or language families, although they predominate in some regions as opposed to others. Corbett (2000) states, "Pluractional marking is an areal feature attested not only in Chadic, but also in a variety of Niger-Congo and Nilo-Saharan languages...." It is probably true that the specific formation, functioning, and meaning of pluractionals may in some cases be areal (if not characteristic of a language family), but pluractionals as such are documented all over the 
world. It is very possible, although I have never seen any discussion of this, that there are more languages in the world that have pluractionals than do not, i.e., this is a very common rather than an exotic feature.

\subsection{Derivational stem formation}

The plurality in pluractionals is an inherent property of verb stems: it is not a case of subject-verb agreement. Following up on observations by Durie (1986) and Mithun (1988), Corbett (1998: 3) notes that, "genuine verbal number [by which he means 'pluractionality'] (rather than nominal number found on verbs by agreement) is typically derivational". This being the case, one would expect that pluractional verb stems should serve naturally as the input to other derivations and inflections. In (1) I present a few illustrative examples from Hausa drawn from the many that could be provided.

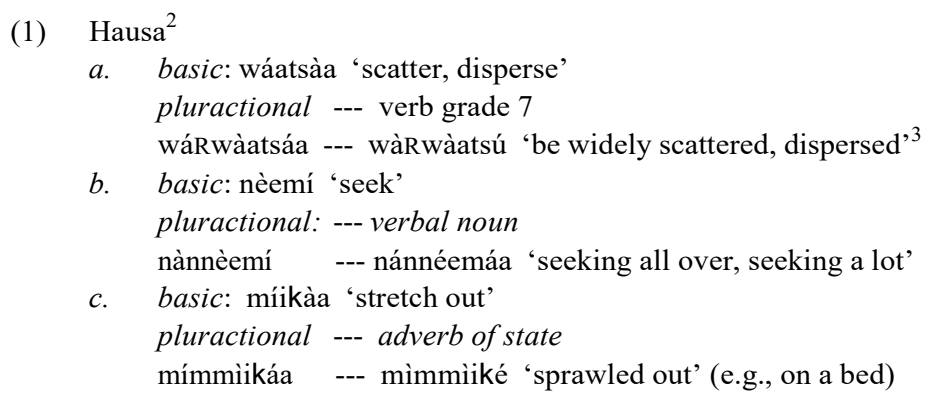

In principle, there is thus no reason why pluractional verbs should not be able to inflect to show subject-verb concord, i.e., become what traditionally were called plural verbs. This in fact is possible and is attested in a small number of Chadic languages belonging to the Bole-Ngamo subgroup. As seen in the

2 Transcription note: The hooked letter $\mathrm{k}$ and the digraph ts are glottalized ejectives; $\mathrm{R}$ is a roll/trill which partially contrasts with $\mathrm{r}$, a retroflex flap. Long vowels are indicated by double letters, with high tone (') and low tone (') marked on the first letter only.

3 Hausa has a number of morphologically distinct verb forms, which are reminiscent of the binyanim of Hebrew and other Semitic languages. In Hausa some of these are basic and some denote such categories as partitive, totality, deprivative, action or movement away (efferential), and action or movement hither (ventive). These forms, which are indicated primarily by tone pattern and final vowel, are referred to as "grades" (see Newman 2000, chapter 74). Grade 7, which is shown in the example, indicates action well done, the potentiality of action, or an agentless passive. 
examples in (2), the pluractional stem in Ngamo is formed either by reduplication or by infixation. Plural agreement between the subject and the verb, on the other hand, which is required in all three persons is marked, inter alia, by an affix -an-. The third person subject pronouns, which precede the verb, are usually omitted, the number of the subject thus being indicated by the inflected verb form. (The suffix $-k \hat{o}$, is a perfective marker whose complex usage is not relevant here.)

(2) Ngamo (Schuh, personal communication)

$\begin{array}{llll}\begin{array}{l}\text { basic } \\ \text { hìncfâ }\end{array} & \text { 'he stood up' } & \begin{array}{l}\text { pluractional } \\ \text { hìhìnfâ }\end{array} & \text { 'he stood up repeatedly' } \\ \text { hìncfànkô } & \text { 'they stood up' } & \text { hìhìncfànkô } & \text { 'they stood up repeatedly' } \\ \text { hàtâ } & \text { 'he went out' } & \text { hàktâ } & \text { 'he went out numerous times' } \\ \text { hàtànkô } & \text { 'they went out' } & \text { hàktànkô } & \text { 'they went out numerous times' } \\ \text { mâ } & \text { 'he returned' } & \text { màpyâ } & \text { 'he returned repeatedly' } \\ \text { mànkô } & \text { 'they returned' } & \text { màpyànkô } & \text { 'they returned repeatedly' }\end{array}$

\subsection{Ergative-like}

To the extent that there is a relationship between pluractional verbs and nominal arguments, it tends to be ergative-like, i.e., the fit is not with the subject as such, but rather with the subject of intransitive verbs and the object of transitives (see Frajzyngier 1985). Greenberg (1991: 584) speaks of "natural ergativity in plural verbs" [by which he means pluractionals] and in individual languages this is commonly described. Within Chadic, for example, the "natural ergativity" was noted by linguists long before they had a clear understanding of the pluractional concept, see Hoffmann (1963) for Margi and Carnochan (1970) for Bachama.

\subsection{Reduplication}

Pluractionals are commonly indicated by reduplication: "The most common form of number marking over multiple lexical categories is reduplication" (Mithun 1988: 218). This fact has been noted independently and repeatedly by scholar after scholar (e.g., Dahl 1999). In pluractionals, reduplication is sometimes total, sometimes partial. The partial reduplication may be a hefty $\mathrm{CVC}$, or it may be a single consonant, assuming, as often seems reasonable, that one wants to interpret gemination as a manifestation of reduplication. Depending on the language the reduplication may be infixal, prefixal, and/or suffixal. Sometimes the reduplication is the full marker of pluractionality, sometimes it is accompanied by other morphophonological changes. All of these possibilities are manifested in the approximately 140 or so languages 
that make up the Chadic family. In short, there is remarkable variation when it comes to specifics, but what remains strikingly constant is the iconic relationship between reduplication and multiple actions and events.

\subsection{Suppletion}

The seminal studies of Cusic (1981) and Durie (1986) specifically comment on the fact that pluractionals commonly display suppletive forms, something that is not very common in subject-verb number agreement. Durie (p. 356) reports that he found verbal number indicated by suppletion in some 40 languages from diverse parts of the world. In combing the literature one has to be careful about statements regarding suppletion - on closer inspection many of the examples cited as suppletion are not - but real examples of suppletion do in fact exist and are quite striking. Here in (3) are selected examples from North America (Shoshone), the Caucasus (Ingush), southern Nigeria [Niger-Congo] (Obolo), and northern Nigeria [Chadic] (Sura).

(3) a. Shoshone (Houser et al. 2006)

$\begin{array}{lll}\text { basic } & \text { gloss } & \text { pluractional } \\ \text { to'eh } & \text { 'emerge' } & \text { küa } \\ \text { pahi } & \text { 'fall off' } & \text { sawü'i }\end{array}$

b. Ingush (Bruhn 2007)

basic gloss $\quad$ pluractional

uozh 'fall' lieg

c. Obolo (Aaron 1996/97)

$\begin{array}{lll}\text { basic } & \text { gloss } & \text { pluractional } \\ \text { kpuk } & \text { 'chop' } & \text { s::p } \\ \text { fieek } & \text { 'slice' } & \text { sek } \\ \text { t::k:: } & \text { 'pour' } & \text { gwook } \\ \text { m::n:: } & \text { 'take' } & \text { chiaa } \\ \text { na a } & \text { 'depart' } & \text { yat }\end{array}$

d. Sura (Jungraithmayr 1963)

$\begin{array}{lll}\text { basic } & \text { gloss } & \text { pluractional } \\ \text { taa } & \text { 'fall' } & \text { cfiyo } \\ \text { t££ } & \text { 'tear, break' } & \text { yila } \\ \text { ma } & \text { 'take' } & \text { ghar } \\ \text { naa } & \text { 'see' } & \text { liyap } \\ \text { can } & \text { 'cut' } & \text { saa } \\ \text { l::p } & \text { 'get dressed' } & \text { jwal }\end{array}$




\subsection{Semantic characterization}

Unlike noun plurality, which is, or at least which we tend to think is, semantically fairly straightforward in that it connotes number and not much else, pluractional verbs have a rich and varied semantics. Pluractionals indicate multiplicity of action or event in some manner or other but with a wide variety of manifestations. Pluractionals indicate repetition, frequentativeness, habitualness, and succession of action over time; expansiveness and scattered distribution in space; actions affecting multiple persons, animals, or objects, either in large number or individually; and actions (often embodied in intransitive verbs) carried our by multiple persons, either as a group or individually. Languages differ greatly in how this semantic richness is embodied. In some, the pluractional verbs encompass the wide range of these meanings. In others, the pluractionals only denote some portion of the attested semantic possibilities or, alternatively, denote more than one subset of pluractional semantics but by different morphological means.

\subsection{Connection with other verbal properties}

In some languages what appear to be pluractional verbs truly reflect verbal plurality in the sense of indicating the plurality of the action or of the event; but in others these verb forms may be more closely related to aspect, or Aktionsart, or other semantic categories, see, for example, Xrakovskij (1997) and Shluinsky (2008). In the Niger-Congo family, for example, many languages have an elaborate system of "verbal extensions", with categories such as reversive, reflexive, reciprocal, causative, indirect causative, applicative, passive, habitual, stative, and imperfective. In such languages "pluractional" may be just another verbal extension or it may simply be a semantic component of some other extension or extensions rather than being a distinct form belonging to the domain of plurality.

\section{Observations and questions about pluractionals}

\subsection{Productivity}

Where it occurs, subject-verb agreement usually applies across the board to all verbs. With pluractionals, on the other hand, languages differ. In Hausa every verb potentially occurs as a pluractional. Within Chadic, this apparently is also the case for Margi (Hoffmann 1963). According to Jungraithmayr (1963), a small number of verbs in Sura, mostly CVC and CVVC, have a special "plural form" although what "a number of" means is not spelled out. 
In Kera (Ebert 1979) the number of pluractionals also appears to be limited, and when one gets to Kanakuru (Newman 1974), the exact number of pluractional verbs can be counted, namely seven, i.e., 'pass by', 'tie', 'shoot', 'get out', 'disrobe', 'die', and 'go out / take out' (see (6) below).

Crosslinguistically, about $20 \%$ of the verbal lexicon in Chechen is reported to be marked for pluractionality ( $\mathrm{Yu}$ 2003), whereas in Ingush, a sister language, some 80 verbs (out of how many?) are recorded as having pluractional counterparts (Bruhn 2007); but most studies are silent on the number. The questions to ask then are: (a) if a language has pluractionals, how productive will the formation be? and (b) assuming that only some verbs have pluractionals, can one generalize as to which verbs will allow them and which not, e.g., transitive vs. intransitive, or verbs of contact vs. verbs of sensation?

The question of productivity is especially apt when it comes to suppletive pluractional forms. How many does the language have? Most sources are not explicit about this, i.e., when they give examples, one is not sure whether they are giving illustrative examples or whether the list represents all of the attested cases. Occasionally this information is provided, e.g., Obolo suppletives are said to constitute $1 \%$ of the verb list (Aaron 1996/97) and Krongo is described as having 15 suppletive pluractionals (Reh 1985), but it usually is not. We can assume that the number of suppletive forms is going to be small, but how many? And perhaps even more interesting than raw numbers, if suppletive pluractionals exist, which verbs are they? Do they tend to fall into certain semantic or grammatical categories or is there no observable pattern?

\subsection{Frozen pluractionals}

The term "frozen pluractional" applies to verbs that are reduplicated or which appear in some other manner to be pluractional in form even though synchronically the verb is not derived from nor directly related to some occurring basic stem. Sometimes the frozen pluractional reflects a process that is still productive in the language. Other times the frozen form does not relate to a process that is currently operative in the language, but the process can be recognized as pluractional by virtue of the verb's canonical shape or its semantics. In other words, the frozen forms are most likely vestiges of constructions that would have existed at an earlier historical period in the language.

Frozen pluractionals are well attested in Chadic, although seldom described as such. In Margi almost all verbs can undergo pluractional formation, which is indicated either by full reduplication or, more often, initial CVreduplication. A handful of verbs exhibit $\mathrm{CV}$ - reduplication in the base form; 
these qualify as frozen pluractionals, see (4a). Ngizim has productive pluractional formation marked by suffixal reduplication to the right. By contrast, the many synchronically monomorphemic verbs that are reduplicative in form, i.e., that qualify as frozen pluractionals, manifest prefixal or infixal reduplication, see (4b). Bole has a reasonable number of synchronic pluractionals although the process is far from productive. These verb stems are formed by a variety of means including infixation, gemination, and prefixal reduplication. Bole also has a large number of synchronically basic, non derived verbs with internal geminate consonants. Since gemination in simple lexical items is untypical of Chadic languages, we can take these verbs with geminates to be frozen pluractionals, see (4c). In Hausa, where frozen pluractionals are extremely common, these verb forms may themselves undergo synchronically productive pluractional formation, see (4d). The possibility of forming pluractionals of frozen pluractionals is rarely described for other languages, but it probably occurs quite readily.

(4) a. Margi (Hoffmann 1963)

\begin{tabular}{|c|c|c|}
\hline $\begin{array}{l}\text { i. Basic } \\
\text { pahla } \\
\text { tida }\end{array}$ & $\begin{array}{l}\text { 'break (e.g., a bottle)' } \\
\text { ‘creep' }\end{array}$ & $\begin{array}{l}\text { pluractional } \\
\text { papahla 'smash, } \\
\text { titida 'creep around' }\end{array}$ \\
\hline \multicolumn{3}{|c|}{ ii. Frozen pluractionals: } \\
\hline tatal & 'scatter (intr.)' & \\
\hline atam & 'touch, feel' & \\
\hline a acfa & 'shake' & \\
\hline u uni & 'murmur' & \\
\hline sasu'u & 'endure' & \\
\hline
\end{tabular}

b. Ngizim (Schuh 1981)
i. Basic pluractional
manu 'spend a year' mananu 'spend many years'
varku 'shoot' varkaku 'shoot many or repeatedly'
ii. Frozen pluractionals:
tatamu 'harvest beans' <*tamu ${ }^{5}$
papku 'scrape' <*paku
zazgu 'rub an itch' <*zagu
vargaganu 'roll around on the ground' <*varganu
zangagcfu 'doze off' <*angacfu
cahlahlanu 'play with one's food' $\quad<*$ cahlanu

4 Here $/ \mathrm{hl} /$ is a lateral fricative.

5 Compare Hausa túmàa 'pick off grain from head' 
c. Bole (Gimba 2000)

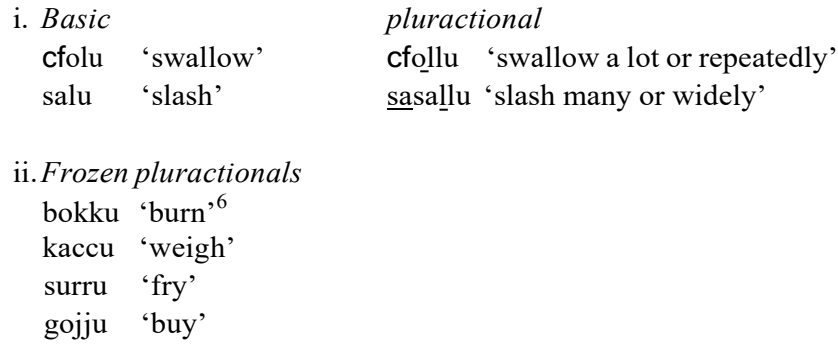

d. Hausa

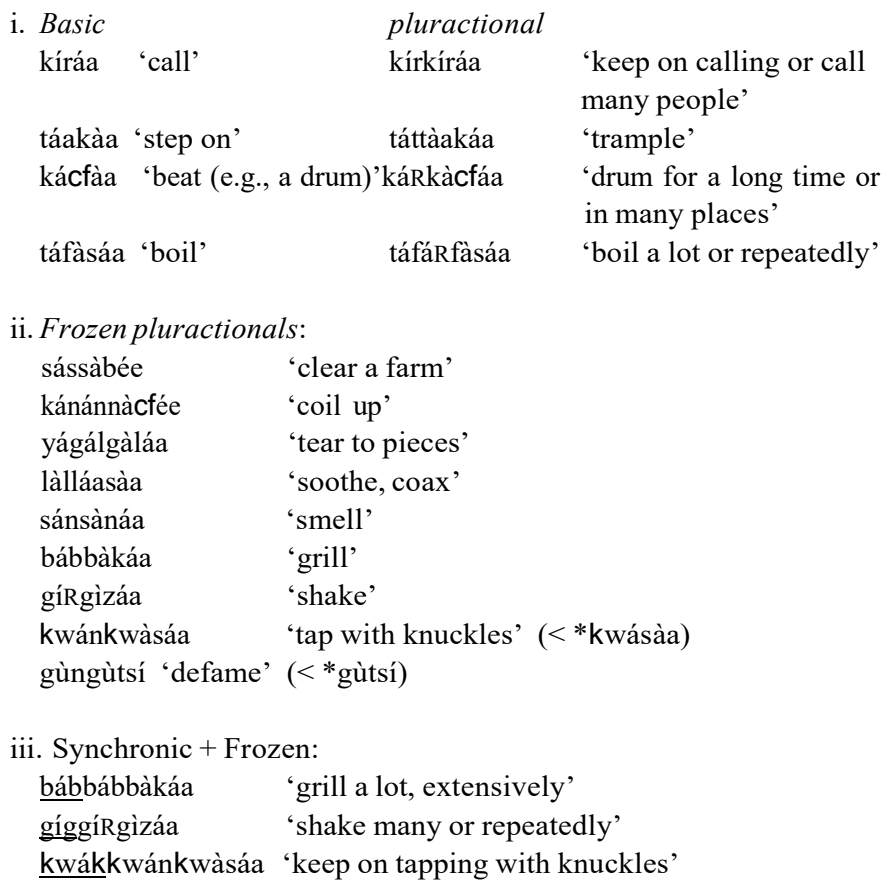

The syllable-final rolled /R/ that appears in place of the reduplicated coronal obstruent in examples such as káRkàdáa 'keep beating a drum' and gíRgìzáa 'shake' is phonologically regular (see Newman 2004). By contrast, the syllable-final $/ \mathrm{n} /$ found in frozen pluractionals such as kwánkwàsáa 'tap with knuckles' and gùngùtsi 'defame' is phonologically totally aberrant and something for which we lack a good explanation. This $/ \mathrm{n} /$ is not to be found in

6 Compare the Hausa frozen pluractional bábbàkáa 'grill, roast'. 
productive pluractionals, where the erstwhile syllable-final consonant in the partially reduplicated syllable appears either as such, e.g., kírkíráa 'call many or often', as /R/ replacing a coronal obstruent, e.g., káRkà dáa 'keep beating a drum', or as the first part of a geminate consonant, e.g., táttàakáa 'trample'.

What we can take to be frozen pluractionals are also found elsewhere in Afroasiatic outside of Chadic. For example, consider the following reduplicated lexical verbs in Tuareg (Dingemanse 2008), where the pluractional semantics is evident: faratfarat 'sprout up here and there'; fanagfanag 'waddle like a duck'; na-fadfad 'tremble profusely'. And then one can point to the situation in Semitic, where numerous scholars have long surmised that supposedly monomorphemic triconsonantal verb stems with the 2 nd and 3rd consonants identical were probably derived plural/pluractional forms (see Frajzyngier 1979 and Greenberg 1991).

The existence of frozen pluractionals raises a number of questions. First, how common are they in the languages of the world? Are they essentially limited to specific families or language areas or is their occurrence fairly widespread around the globe? Do frozen pluractionals pattern grammatically with productive pluractionals, the only difference being that they lack a nonpluractional counterpart, or have they undergone lexical reclassification and semantic bleaching such that synchronically they have become underived, monomorphemic basic verbs? Finally, can one identify morphological or semantic classes of verbs that are more likely than others to develop into frozen pluractionals?

\subsection{Hyper-pluractionals}

Hausa (Newman 2000) manifests pluractionals built on pluractionals, where the initial construction involves an archaic infixal reduplicative construction and the other construction uses the more common prefixal reduplication, see (5). The exact semantics of these doubly-marked forms is not clear, but the feeling of native speakers is that they are stronger and more extensive than the normal pluractionals.

$\begin{array}{llll}\text { (5) } \begin{array}{lll}\text { Hausa } \\ \text { basic }\end{array} & \text { gloss } & \text { pluractional } & \text { hyper-pluractional } \\ \text { mákàláa } & \text { 'lodge, stick' } & \text { mákálkàláa } & \text { mámmákálkàláa } \\ \text { máakùrée } & \text { 'choke, strangle' } & \text { máakúrkùrée } & \text { mámmáakúrkùrée } \\ \text { zábàkáa } & \text { 'boil' } & \text { zábábàkáa } & \text { zázzábábbàkáa } \\ \text { gírcfàa } & \text { 'uproot' } & \text { gíní́RRìcfáa } & \text { gíggíníRRìcfáa } \\ \text { tártsèe } & \text { 'smash' } & \text { tárárràtsée } & \text { táttárárràtsée }\end{array}$

Although accounts of what I am calling "hyper-pluractionals" are scarce, a few do exist (see Dahl 1999 and Wolff 1983). My guess is that this pheno- 
menon is not all that uncommon in the languages of the world, but rather has simply been overlooked and inadequately explored and described. This is clearly a phenomenon that calls for further investigation.

\section{4. (Pseudo-)Agreement}

Our starting point in recognizing and describing pluractionals has been that they are semantically-endowed derivational forms having nothing grammatically to do with agreement. And this is usually the case. However, there are languages where the pluractionals have developed agreement properties. For example, in Bachama (Carnochan 1970), a Central Chadic language, pluractional verbs normally occur in sentences that contains a plural subject of an intransitive verb or a plural object of a transitive verb. This is not grammatically required, i.e., this is not a case of strict, formal agreement, but it appears to be the norm. In Mupun (Frajzyngier 1993), a West Chadic language, this tendency appears to have gone further in that "although a plural verb may be used with a singular object to indicate an action performed with some intensity, or many times, the singular form of a verb is generally ruled out with a plural object" (p. 60). And when one gets to Kanakuru (Newman 1974), which only has seven erstwhile pluractional verbs, these no longer have pluractional semantics at all but rather their use has become grammatically determined, i.e., the language now has obligatory agreement, albeit of an ergative type, see (6).

(6) Kanakuru (Newman 1974)

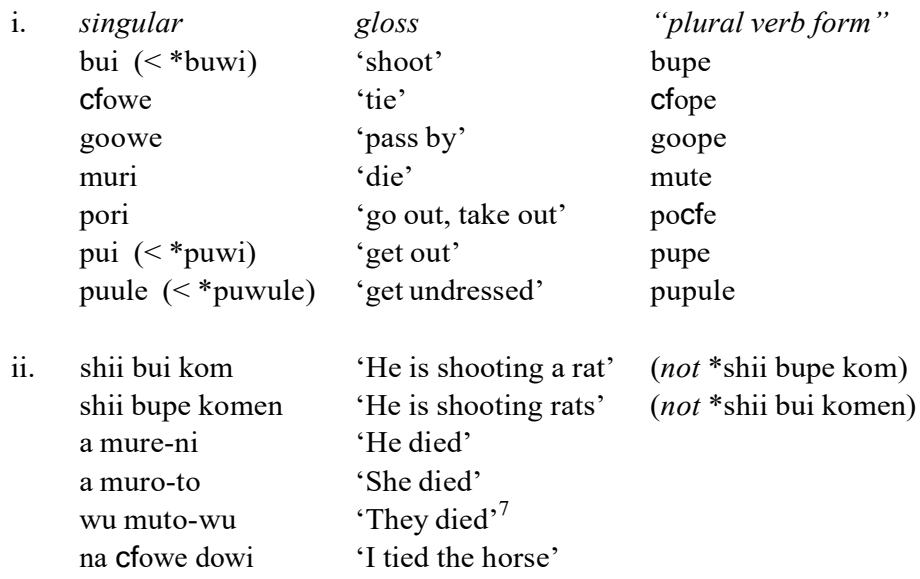

7 The suffixes $-n i$, -to and -wu are ICP's ("intransitive copy pronouns"), which are required with all verbs when used intransitively. 


$\begin{array}{ll}\text { nacfope donjini } & \text { 'I tied the horses' } \\ \text { dowi a cfowe-ni } & \text { 'The horse was tied up' } \\ \text { donjini wu cfopo-wu 'The horses were tied up' }\end{array}$

\subsection{Morphological differences in pluractionals}

Pluractional is a useful cover term that allows us to recognize and bring together similar phenomena formerly described with disparate terms; but it should not be allowed to hide real differences where they exist. While we gain in recognizing pluractionals, there is a danger that we will allow ourselves to oversimplify and overlook real differences. One has to acknowledge the possibility of a language having more than one type of pluractional. For example, Kwakiutl (Boas 1947) has 3 distinct types of pluractionals: (a) indicating several subjects, (b) indicating an action occurring at the same time on different parts of an object, and (c) repeated action. Similarly, Obolo (Aaron 1996/97), a southern Nigerian Cross River language, has 3 different kinds of pluractionality, which are described as: (a) distributive plurality (often indicated by suppletive forms), (b) iterative plurality (formed by reduplication), and (c) extensive iterative plurality. Examples from Kera, an East Chadic language, illustrate clearly distinct formations in a single language. In Kera, pluractional verbs in the general sense of the term are derived by devoicing the initial consonant; whereas the language also has a separate iterative construction marked by adding $-t$ to the root, see (7):

(7) KERA (Ebert 1979)

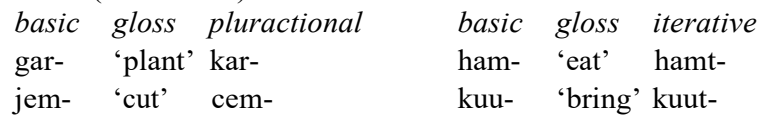

In other languages however, different markers are often alternative allomorphs of a single pluractional formation although these could easily represent the merger of originally distinct morphemes. That is, even if the pluractional formatives constitute a single category now, it is possible that historically speaking they were different. In some cases the merger of originally distinct forms may show up synchronically as "double marking" as seen in Pero, a West Chadic language, where pluractionals of some verbs are indicated by gemination and by the addition of a suffix -to or -co (where $c$ represents the affricate $[\mathrm{ch}]$ ), the suffix obviously being cognate with the Kera iterative $-t$ ), see (8). 
(8) PERO(Frajzyngier 1989)

\begin{tabular}{|c|c|c|}
\hline basic & gloss & pluractional \\
\hline camu & 'twist rope' & cammuco $\left(\right.$ not ${ }_{-}^{*}$ cammo nor $*_{-}$camuco) \\
\hline ceko & 'lose' & cekḱuto \\
\hline ifu & 'catch' & iffuco \\
\hline eco & 'thatch' & beccuco \\
\hline
\end{tabular}

\subsection{Pluractionals vs. concordial "plural verbs"}

From the time of Bybee's paper (1984), and probably before and continuing since then, there has been an implicit assumption that the concordial and nonconcordial plural verb forms are subclasses (inflectional vs. derivational) of a single verb plural category. But do they really have anything in common? My guess is probably not. Most likely the grouping of these non-like things together is an artifact of our linguistic tradition and old terminology and is not justified on empirical or analytical grounds. This is an important matter that needs to be investigated in detail. Questions that need to be looked at include, but are not limited to, (a) to what extent is person marking incorporated in plural as opposed to pluractional verb forms? (b) is reduplication a more common formative in pluractional as opposed to plural verb forms? and (c) how does suppletion fit into the picture?

\subsection{Pluractionals vs. noun plurals}

One of Lasersohn's (1995) goals was to provide a unified semantic analysis for noun plurals and verb pluractionals. Van Geenhoven (2004) describes pluractionals as the "analog" of noun plurals, and scholars in the Chadic field, e.g., Frajzyngier (1977) and Wolff (1977), have pointed to similarities between noun plural and verb pluractional marking. However, in many languages noun plurals and verb pluractionals do not really employ the same formation, a counter-finding described for Chadic in Newman (1990). For example, the incidence and type of reduplication found in pluractionals as opposed to noun plurals are far from the same. Moreover they tend not to be parallel in many other respects, e.g., with nouns the category of dual is far from rare, whereas with pluractional verbs duals are attested much less often. By casually grouping nominal and verbal plurality together, as if they were manifestations of a higher level category PLURAL, as reflected in the title of my comparative Chadic monograph (Newman 1990) and in the title of various conferences covering noun plurals, inflectional verb plurality, and verb pluractionality, we have unconsciously misled ourselves into taking something for granted that ought not be accepted at face value. We do not know 
the full answer to this yet, but a good working hypothesis is that pluractionals as a category are unrelated to noun plurality in any meaningful sense, and where they are related, this is the exception rather than the rule. To the extent that they display similarities in form, this is not because of any special categorial relationship, but rather because of the influence of phono-semantic iconicity.

\section{Conclusion}

The study of pluractional verbs is a wide-open, exciting field ripe for further study. Building on the theoretical ideas developed during the past few decades, scholars can now describe pluractionals in individual languages in a more insightful manner and have the core knowledge and empirical base to undertake detailed comparative work, whether within a language family, whether limited to particular geographical areas, whether viewed as a contact phenomenon, or whether studied from a broad typological perspective. My intention in this presentation has been to raise questions to explore and to provide conceptual tools to facilitate future research.

\section{References}

Aaron, Uche E. (1996/97). "The category of number in Obolo verbal morphology." Journal of West African Languages 26(1): 49-76.

Bar-el, Leora. (2008). "Verbal number and aspect in Skwxwú7mesh." in Aspect et pluralité d'événements, Lucia M. Tovena (ed.), 31-54. (Recherches Linguistiques de Vincennes, 37).

Becher, Jutta. (2002). "Verbalextensionen in den Atlantischen Sprachen." Hamburger Afrikanistische Arbeitspapiere (HAAP) 1: 1-38.

Beck, Sigrid, \& Arnim von Stechow. (2007). "Pluractional Adverbials." Journal of Semantics 24: 215-254.

Bendjaballah, Sabrina, \& Chris H. Reintges. (2009). “Ancient Egyptian verbal reduplication: Typology, diachrony, and the morphology-syntax interface." Morphology 19(2): 135-157.

Bissell, Teal. (2002). "Avoidance of the marked in Miya pluractional allomorphy." MIT Working Papers in Linguistics 42: 1-22.

Blench, Roger (2005). "Is there a boundary between Plateau and Jukunoid?" Unpublished ms (paper presented at the Vienna Jukunoid workshop). 
n.d. "Plural verb morphology in Fobur Izere." Unpublished ms.

Boas, Franz. (1947). "Kwakiutl grammar with a glossary of the suffixes." Transactions of the American Philosophical Society 37(3): 201-377.

Bowern, Claire L. (2004). Bardi Verb Morphology in Historical Perspective, Ph.D. thesis, Harvard University.

Brooks, Bryan. (1991). "Pluractional verbs in African languages." Afrikanistische Arbeitspapiere 28: 157-168.

Bruhn, Daniel. (2007). "Distributive pluractionality and plurality in Ingush.” Unpublished ms.

Bybee, Joan. (1984). "Diagrammatic iconicity in stem/inflection relations." In: Iconicity in Syntax, John Haiman (ed.), 11-47. Amsterdam: John Benjamins. (1985). Morphology: A Study of the Relation between Meaning and Form. Amsterdam: John Benjamins.

Caballero, Gabriela. (2006). “'Templatic backcopying' in Guarijio abbreviated reduplication." Morphology 16(2): 273-289.

Carnochan, Jack. (1970). "Categories of the verbal piece in Bachama." African Language Studies 11: 81-112.

Childs, G. Tucker (1995). A Grammar of Kisi. Berlin: Mouton de Gruyter.

Collins, Chris. (2001). "Aspects of plurality in =Hoan." Language 77: 456-476.

Corbett, Greville. (1998). "Prototypical inflection: Implications for typology." Yearbook of Morphology 1998, 1-22. Dordrecht: Kluwer.

------ (2000). Number. Cambridge: Cambridge University Press.

Creissels, Denis, Gerrit J. Dimmendaal, Zygmunt Frajzyngier \& Christa König. (2008). "Africa as a morphosyntactic area." Chapter 4 in Heine \& Nurse (eds.), $86-150$.

Crevels, E. I. (2006). “Aspects of pluractionality in Itonama.” Unpublished ms., Radboud University Nijmegen.

$<$ http://www.narcis.info/publication/RecordID/oai:repository.ubn.ru.nl:2066\%2F4 $1521>$

----- n.d. "Verbal number in Itonama." Unpublished ms.

Cusic, David D. (1981). Verbal Plurality and Aspect. Ph.D. dissertation, Stanford University.

Dahl, Östen. (1999). “Aspect: Basic principles.” In Concise Encyclopedia of Grammatical Categories, Keith Brown \& Jim Miller (eds.), 30-37. Amsterdam: Elsevier.

Dimmendaal, Gerrit. (2003). "Review of Greville Corbett, Number." Journal of Linguistic Anthropology 13(2): 241-243.

Dingemanse, Mark (2008). "Expressivity in Berber, part I: Expressive verbs in Tuareg." <http://ideophone.org/tuareg-expressive-verbs/>

Dressler, Wolfgang. (1968). Studien zur verbalen Pluralität. Iterativum, Distributivum, Durativum, Intensivum in der allgemeinen Grammatik, im Lateinischen und Hethitischen. Vienna: Hermann Böhlaus Nachfolger.

Durie, Mark. (1986). "The grammaticalization of number as a verbal category." $B L S$ 12: $355-370$

Ebert, Karen H. (1979). Sprache und Tradition der Kera (Tschad), Teil 3: Grammatik. (Marburger Studien zur Afrika- und Asienkunde, Serie A, Afrika, 15) Berlin: Dietrich Reimer. 
Elders, Stefan. (2001). "Defining ideophones in Mundang." in Ideophones, F. K. Erhard Voeltz \& Christa Killian-Hatz (eds.), 97-110. Amsterdam: John Benjamins.

el Zarka, Dina. (2005). "On the borderline of reduplication: gemination and other consonant doubling in Arabic morphology." In: B. Hurch (ed.) (2005), 369-394.

Faller, Martina. (2007). "The ingredients of reciprocity in Cuzco Quechua." Journal of Semantics 24: 255-288.

Fassi Fehri, Abdelkader. (2003). "Verbal plurality, transitivity, and causativity." In Research in Afroasiatic Grammar II, Jacqueline Lecarme (ed.), 151-185. Amsterdam: John Benjamins.

Frajzyngier, Zygmunt. (1977). "The plural in Chadic." In: Papers in Chadic Linguistics, Paul Newman \& Roxana Ma Newman (eds.), 37-56. Leiden: AfrikaStudiecentrum.

(1979). "Notes on the $\mathrm{R}_{1} \mathrm{R}_{2} \mathrm{R}_{2}$ stems in Semitic." Journal of Semitic Studies 24: $1-12$.

(1985). "Ergativity, number, and agreement." BLS 11: 96-106.

(1989). A Grammar of Pero. (Sprache und Oralität in Afrika, 4) Berlin: Dietrich Reimer.

(1993). A Grammar of Mupun. (Sprache und Oralität in Afrika, 14) Berlin: Dietrich Reimer.

Garrett, Andrew. (2001). "Reduplication and infixation in Yurok: Morphology, semantics, and diachrony." International Journal of American Linguistics 67(3): 264-312.

van Geenhoven, Veerle. (2004). "For-adverbials, frequentative aspect and pluractionality." Natural Language Semantics 12: 135-190.

(2005). "Atelicity, pluractionality, and adverbial quantification." In Perspectives on Aspect, Henk Verkuyl, Henriette de Swart, \& Angeliek van Hout (eds.), 107-124. Dordrecht: Springer.

Gerhardt, Ludwig. (1984). "More on the verbal system of Zarek (Northern Nigeria)." Afrika und Übersee 67: 11-30.

------ (2002). "Pluraktionale Verben in einigen Benue-Congo-Sprachen des nigerianischen Plateau." Hamburger Afrikanistische Arbeitspapiere (HAAP) 1: 37-58.

Gimba, Alhaji Maina. (1995). "Pluractionals in Bole." In Studia Chadica et Hamitosemitica: Akten des Internationalen Symposions zur Tschadsprachenforschung, Dymitr Ibriszimow \& Rudolf Leger (eds.), 180-183. Cologne: Rüdiger Köppe.

------ (2000). Bole Verb Morphology. Ph.D. dissertation, UCLA.

Gouffé, Claude. (1975). "Redoublement et réduplication en haoussa: Formes et fonctions." Bulletin de la Société de Linguistique de Paris 70(1): 291-319.

Greenberg, Joseph H. (1966)."Language universals." In Current Trends in Linguistics III: Theoretical Foundations, T. A. Sebeok (ed.), 61-112. The Hague: Mouton. (1991). "The Semitic 'intensive' as verbal plurality." In Semitic Studies in Honor of Wolf Leslau, Alan S. Kaye (ed.), vol. 1, 577-587. Wiesbaden: Harrassowitz.

Greenberg, Yael. (2010). "Event Internal Pluractionality in Modern Hebrew: A Semantic Analysis of One Verbal Reduplication Pattern." Brill's Annual of Afroasiatic Languages and Linguistics 2: 119-164 
Gu, Yang, Hongyong Liu, \& Foong Ha Yap. (2007). "Reduplication and pluractionality." Unpublished abstract.

Haji-Abdolhosseini, Mohammad, Diane Massam, \& Kenji Oda. (2002). "Number and events: Verbal reduplication in Niuean.” Oceanic Linguistics 41(2): 475-492.

Heine, Bernd, \& Derek Nurse (eds.) (2000).African Languages: An Introduction. Cambridge: Cambridge University Press.

(2004). Les langues africaines. French edition of the preceding, prepared by $\mathrm{H}$. Tourneux \& J. Zerner. Paris: Karthala.

------ (2008). A Linguistic Geography of Africa. Cambridge: Cambridge University Press.

Hoffmann, Carl. (1963). A Grammar of the Margi Language. London: Oxford University Press.

Houser, Michael J., Reiko Kataoka, \& Maziar Toosarvandani. (2006).”Pluractional reduplication in Northern Paiute." Paper presented at a Friends of Uto-Aztecan Languages Conference, University of California, Berkeley.

Hurch, Bernhard (ed.). (2005). Studies on Reduplication. Berlin: Mouton de Gruyter.

Hyman, Larry M. (2007). "Niger-Congo verb extensions: Overview and discussion." In Selected Proceedings of the 37th Annual Conference on African Linguistics, Doris L. Payne \& Jaime Peña (eds.), 149-163. Somerville, MA: Cascadilla Proceedings Project.

------ (2009)."Perfective, pluractional, and progressive aspect formation in Leggbó." In Topics in Descriptive and African Linguistics: Essays in Honor of Distinguished Professor Paul Newman, Samuel Gyasi Obeng (ed.), 5-28. Munich: LINCOM Europa.

Inkelas, Sharon, \& Cheryl Zoll. (2005). Reduplication: Doubling in Morphology. Cambridge: Cambridge University Press.

Iordachioaia, Gianina, \& Elena Soare. (2007). "Event internal pluractional verbs in some Romance languages." Paper presented at the twenty-first Symposium on Romance Linguistics, Amsterdam.

Jungraithmayr, Herrmann. (1963). "Die Sprache der Sura (Maghavul) in Nordnigerien." Afrika und Übersee 47: 8-89, 204-220.

Kießling, Roland (1998). "Der Pluraktionalis in Datooga.” In Afrikanische Sprachen im Brennpunkt der Forschung. Linguistische Beiträge zum 12. Afrikanistentag Berlin, 3.-6. Oktober 1996, Ines Fiedler, Catherine Griefenow-Mewis, \& Brigitte Reineke (eds.), 179-196. Cologne: Rüdiger Köppe.

------ (2002). "Verbal plurality in Sandawe." Hamburger Afrikanistische Arbeitspapiere (HAAP) 1: 59-90.

Kießling, Roland, Maarten Mous, \& Derek Nurse. (2008). "The Tanzanian Rift Valley area." Chapter 6 in Heine \& Nurse (eds.) (2008), 186-227.

Kossmann, Maarten. (2004). "Overview of Tuareg phonology, morphology, and syntax." Unpublished ms.

Kouwenberg, Silvia (ed.). (2003). Twice as Meaningful: Reduplication in Pidgins, Creoles and other Contact Languages. London: Battlebridge.

Kropp Dakubu, M. E. (2003). “Aspect agreement constraints in Gurene multi-verb constructions." In Proceedings of the Workshop on Multi-Verb Constructions, Dorothee Beermann \& Lars Hellan. (eds.) (Trondheim Summer School (2003). $<$ http://edvarda.hf.ntnu.no/ling/tross/dakubu.pdf $>$ 
Kwak, Eun-Joo. (1996). “The ambiguity of plurals and distributives.” In ESCOL '95: Proceedings of the 12th Eastern States Conference on Linguistics, M. Przezdziecki \& L. Whaley (eds.), 149-160. Ithaca: Cornell University.

Laca, Brenda. (2004). "Progressives, pluractionals, and the domains of aspect." In: Domaines, Journées d'études linguistiques de Nantes, O. Crouzet, $\mathrm{H}$. Demidache, \& S. Wauquier (eds.), 87-92. <http://halshs.archivesouvertes.fr/halshs-00104641/>

(2006). "Pluractionnalité." In Sémanticlopédie: Dictionnaire de Sémantique, Danièle Godard, Laurent Roussarie, \& Francis Corblin (eds.).

$<$ http://www.semantique-gdr.net/dico/index.php/Pluriactionnalité>

Lasersohn, Peter. (1995). Plurality, Conjunction, and Events. Dordrecht: Kluwer.

Lecarme, Jacqueline. (2004). "Tense in nominals.” In The Syntax of Time, Jacqueline Guéron \& Jacqueline Lecarme (eds.), 441-475. Cambridge, MA: MIT Press.

Lindström, Eva. (2002). Kuot Language and Culture. Ph.D. dissertation, Stockholm University.

Matthewson, Lisa. (2000). "On distributivity and pluractionality." In Semantic and Linguistic Theory X (SALT 10), Brendan Jackson \& Tanya Matthews (eds.), 98114. Ithaca: Cornell University.

(2004). "On the methodology of semantic fieldwork." International Journal of American Linguistics 70: 369-415.

Mithun, Marianne. (1988). "Lexical categories and the evolution of number marking." In Theoretical Morphology, Michael Hammond \& Michael Noonan (eds.), 211234. San Diego: Academic Press.

Mous, Maarten n.d. "The middle and passive derivations in Konso." Unpublished ms.

Müller, Ana, \& Luciana Sanchez-Mendes. (2007). "The meaning of pluractionality in Karitiana." In Proceedings of SULA 4: Semantics of Under-Represented Languages in the Americas (University of Massachusetts Occasional Papers 35).

Newman, Paul. (1974). The Kanakuru Language. Leeds: Institute of Modern English Language Studies, University of Leeds and West African Linguistic Society. (1980). The Classification of Chadic within Afroasiatic. Leiden: Universitaire Pers.

(1989). "The historical change from suffixal to prefixal reduplication in Hausa pluractional verbs." Journal of African Languages and Linguistics 11: 37-44. (1990). Nominal and Verbal Plurality in Chadic. Dordrecht: Foris Publications. (2000). The Hausa Language: An Encyclopedic Reference Grammar. New Haven: Yale University Press.

(2004). Klingenheben's Law in Hausa. Cologne: Rüdiger Köppe.

(2006). "Pluractionals (distributives)." in The Encyclopedia of Language and Linguistics, 2nd ed., 640-641. Oxford: Elsevier.

Newman, Paul, \& Bello A. Salim. (1981). "Hausa diphthongs." Lingua 55: 101-121.

Newman, Roxana Ma, \& Vincent J. van Heuven. (1981). "An acoustic and phonological study of pre-pausal vowel length in Hausa." Journal of African Languages and Linguistics 3: 1-18.

Nurse, Derek, \& Gérard Philippson (eds). (2003). The Bantu Languages. Abingdon, Oxford: Routledge.

Parsons, F. W. (1981). Writings on Hausa Grammar: The Collected Papers of F. W. Parsons, G. L. Furniss (ed.). Ann Arbor: UMI Books on Demand. 
Reh, Mechthild. (1985). Die Krongo-Sprache. Berlin: Dietrich Reimer.

Sapir, Edward. (1917). "Review of C. C. Uhlenbeck, 'Het Passieve Karakter van het Verbum Transitivum of van het Verbum Actionis in Talen van NoordAmerika'." International Journal of American Linguistics 1: 82-86.

Sapir, Edward, \& Morris Swadesh. (1946). "American Indian grammatical categories." Word 2: 103-112.

Satre, Scott Alan. (1999). The Simple Clause in Ngomba. Yaoundé: SIL.

Schuh, Russell G. (1981). A Dictionary of Ngizim. Berkeley \& Los Angeles: University of California Press.

------ (2002). "The locus of pluractional reduplication in West Chadic." Unpublished $\mathrm{ms}<\mathrm{http}: / / \mathrm{www}$.linguistics.ucla.edu/people/schuh/Papers/WC_redup.pdf $>$

Shaw, Patricia A. (2005). “Non-adjacency in reduplication.” In B. Hurch (ed.) (2005), $11-30$.

Shluinsky, Andrey. (2008). "Verbal plurality and aspect: Ways of interaction". Paper presented at the Journées d'études sur la pluralité nominale et verbale 2008. Paris.

Souag, Lameen. (2008). "Reduplication in Siouan-Catawban." MA essay, SOAS.

Soucková, Katerina, \& Malami Buba. (2008). "Intensive plurality: Hausa pluractional verbs and degree semantics." In Linguistics in the Netherlands 2008, Marjo van Koppen \& Bert Botma (eds.), 133-144. Amsterdam: John Benjamins.

Steinkeller, Piotr. (1979). "Notes on Sumerian plural verbs.” Orientalia 48: 54-67.

Tovena, Lucia M., \& Alain Kihm. (2008). "Event internal pluractional verbs in some Romance languages." In Aspect et pluralité d'événements, Lucia M. Tovena (ed.), 9-30. (Recherches Linguistiques de Vincennes, 37).

Veselinova, Ljuba N. (2008). "Verbal number and suppletion." Chapter 80 in The World Atlas of Language Structures Online, Martin Haspelmath, Matthew S. Dryer, David Gil, \& Bernard Comrie (eds.). Munich: Max Planck Digital Library $<$ http://wals.info/feature/80 $>$

Vycichl, Werner. (1970). "Partizipien des Frequentativstammes im Koptischen." Le Muséon 83: 547-549.

Winfield, W. W. (1928). A Grammar of the Kui Language. Calcutta: Baptist Mission Press.

Wolff, Ekkehard. (1977). "Patterns in Chadic (and Afroasiatic?) verb base formations." In Papers in Chadic Linguistics, Paul Newman \& Roxana Ma Newman (eds.), 199-233. Leiden: Afrika-Studiecentrum.

----- (1983). A Grammar of the Lamang Language. Glückstadt: J. J. Augustin.

Wood, Esther J. (2007). The Semantic Typology of Pluractionality. Ph.D. dissertation, University of California, Berkeley.

Wood, Esther J., \& Andrew Garrett. (2001). "The semantics of Yurok intensive infixation." In Proceedings from the Fourth Workshop on American Indigenous Languages, Jeannie Castillo (ed.), 112-126. Santa Barbara: Department of Linguistics, University of California, Santa Barbara.

Xrakovskij, Viktor S. (ed.). (1997). Typology of Iterative Constructions. Munich: LINCOM Europa.

Yu, Alan C. L. (2003). "Pluractionality in Chechen." Natural Language Semantics 11: 289-321.

------ (2007). "The phonology-morphology interface from the perspective of infix- 
ation." In New Challenges in Typology: Broadening the Horizons and Redefining the Foundations, Matti Miestamo \& Bernhard Wälchli (eds.), 35-54. Berlin: Mouton de Gruyter.

in press. "Two patterns of reduplication in Washo." BLS 34.

Zaborski Andrzej. (2006). "Main and secondary functions of derived verbs in Arabic." Lingua Posnaniensis 48: 165-189.

Zimmermann, Malte. (2000). "Pluractional quantifiers: The occasional-construction in English and German." In Semantic and Linguistic Theory X (SALT 10), Brendan Jackson \& Tanya Matthews (eds.), 290-306. Ithaca: Cornell University. (2003). "Pluractionality and complex quantifier formation." Natural Language Semantics 11: 249-287.

Zuraw, Kie. (2002). “Aggressive reduplication.” Phonology 19: 395-439. 
